\title{
Kecenderungan Pola Asuh Permisif dan Kepercayaan Diri dengan Motivasi Berprestasi pada Siswa
}

\author{
Annisa Mentari Fatwati dan Fuadah Fakhruddiana \\ Fakultas Psikologi Universitas Ahmad Dahlan Yogyakarta Jln. Kapas 9 Semaki Yogyakarta \\ Email:fakhruddiana@gmail.com
}

\begin{abstract}
This research was intended to find out the correlation of the tend to permissiveness parenting, self-confidence, and achievement motivation. The subjects were 61 students of VII Class of Junior High School. This research used quantitative method. Data were collected through Achievement Motivation Scale, Scale of Tend to Permissiveness Parenting Style Perception, and Scale of SelfConfidence. Regression analysis and partial correlation were used as analysis techniques.The results showed that there was correlation between tend to permissiveness parenting style and self-confidence to achievement motivation with $R$ value $=.0,588, p=0,000(p<0,01)$. The contribution from two variables to achievement motivation were $34,5 \%$. The partial correlation showed that there was a negative correlation between permissiveness parenting with achievement motivation and a positive correlation between self-confidence with achievement motivation on students. This research was concluded that there is a very significant correlation between the tend to permissiveness parenting, self-confidence, and achievement motivation on students.
\end{abstract}

Keywords: achievement motivation, self-confidence, tend to permissiveness parenting,

\begin{abstract}
ABSTRAK
Penelitian ini bertujuan untuk memperoleh data mengenai hubungan antara kecenderungan pola asuh permisif dan kepercayaan diri dengan motivasi berprestasi pada siswa. Subjek dalam penelitian ini yaitu siswa kelas VII SMP sebanyak 61 orang. Metode yang digunakan adalah metode kuantitatif. Alat pengumpul data yang digunakan dalam penelitian ini adalah Skala Motivasi Berprestasi, Skala Persepsi Kecenderungan Pola Asuh Permisif dan Skala Kepercayaan Diri. Analisis data penelitian dengan menggunakan teknik analisis uji-t yaitu regresi ganda dan korelasi parsial. Berdasarkan dari hasil analisis yang telah dilakukan, hipotesis yang diajukan dalam penelitian yaitu adanya hubungan antara kecenderungan pola asuh permisif dan kepercayaan diri dengan motivasi berprestasi diterima dengan nilai $\mathrm{R}=0,588, \mathrm{p}=0,000(\mathrm{p}<0,01)$. Sumbangan yang diberikan pola asuh permisif dan kepercayaan diri terhadap motivasi berprestasi sebanyak 34,5\%. Hasil korelasi parsial menunjukkan adanya hubungan negatif antara kecenderungan pola asuh permisif dengan motivasi berprestasi dan terdapat hubungan positif antara kepercayaan diri dengan motivasi berprestasi. Kesimpulan dari penelitian ini yaitu terdapat hubungan yang sangat signifikan antara kecenderungan pola asuh permisif dan kepercayaan diri dengan motivasi berprestasi.
\end{abstract}

Kata kunci : Kecenderungan pola asuh permisif, Kepercayaan diri, Motivasi berprestasi. 


\section{PENDAHULUAN}

Menurut Mc Clelland dan Atkinson (Garliah \& Nasution, 2005), motivasi yang paling penting untuk pendidikan adalah motivasi berprestasi, yaitu ketika seseorang berjuang untuk mencapai sukses atau memilih suatu kegiatan yang berorientasi untuk tujuan kesuksesan. McClelland (Farradina, 2012) menambahkan bahwa individu yang mempunyai motivasi berprestasi tinggi akan mempunyai rasa tanggung jawab dan rasa percaya diri yang tinggi, lebih ulet, lebih giat dalam melaksanakan suatu tugas, mempunyai keinginan untuk menyelesaikan tugasnya dengan baik. Siswa di sekolah yang memiliki motivasi berprestasi yang tinggi akan menyadari kewajiban yang sebenarnya sehingga datang tidak sekedar untuk sekolah. Bila motivasi berprestasi seorang siswa tinggi maka siswa tersebut akan memiliki dorongan untuk melampaui proses dengan melakukan usahausaha sesuai tujuannya sehingga dapat meraih kesuksesan. Sedangkan siswa yang memiliki motivasi berprestasi yang rendah, maka siswa tersebut kurang memiliki ketertarikan, kurang ada daya penggerak untuk melakukan usaha-usaha serta kurang ada keinginan untuk berkompetisi sehingga kemungkinan untuk mencapai kesuksesan pun kecil.

Kenyataan di lapangan, tidak sedikit siswa yang memiliki motivasi berprestasi rendah, seperti pada data yang diperoleh dari hasil wawancara di salah satu SMP di daerah Bantul melalui Wakil Kepala Kurikulum, Wali Kelas sekaligus Guru Matematika pada hari Jumat tanggal 15 Maret 2013. Menurut penuturan guru tersebut, banyak siswa kurang memperhatikan guru ketika menjelaskan pelajaran di kelas, kurang menerapkan nasihat yang diberikan oleh guru, dan kurang bersemangat dalam belajar di kelas. Beberapa siswa juga ada yang membolos, terlambat masuk kelas, dan sedikitnya siswa yang mengerjakan PR. Selain itu juga tampak keingintahuan siswa yang rendah sehingga tidak mau bertanya ketika proses belajar berlangsung. Berdasarkan hasil observasi pada hari Selasa tanggal 2 April 2013, diperoleh data yang cukup sesuai dengan hasil wawancara. Hal tersebut terlihat dari ketika guru sedang menjelaskan pelajaran ada beberapa siswa yang tampak mengobrol, bermain-main kertas, menaruh kepala di meja, memukul-mukul meja, menaikkan kaki di meja, makan, bermain jangkar, saling memukul kepala, saling mengolok satu sama lain, bahkan ada yang tidak mencatat dari apa yang dijelaskan oleh guru meskipun telah ditegur dan dimarahi oleh guru. Di tengah jam pelajaran, ada siswa yang masih bertanya mengenai materi yang diajarkan saat itu dan halaman berapa yang sedang dijelaskan oleh guru. Ketika proses pembelajaran berlangsung, tidak ada siswa yang bertanya mengenai materi yang dijelaskan oleh guru. Ketika guru meminta para siswa mengerjakan tugas, kebanyakan mereka hanya mengobrol, bahkan ada yang tidur. Saat guru meminta tugas untuk dikumpulkan, beberapa di antaranya ada yang mencontek pekerjaan temannya dan ada yang tidak mengumpulkan. Saat pergantian jam pelajaran dan banyak siswa yang keluar dari kelas. Ketika jam istirahat telah berakhir, masih banyak siswa yang berada di luar kelas, tidak segera bergegas masuk kelas, bahkan banyak di antaranya ada yang terlambat masuk hingga setengah jam. Perpustakaan juga terlihat sepi, tidak ada satu siswapun yang membaca-baca buku, bahkan perpustakaan dijadikan tempat makan dan mengobrol ketika jam istirahat.

Kompas (Junaedit, 2012) juga memberitakan bahwa 79\% siswa niat belajar karena akan mengikuti UAN. Hal itu menunjukkan bahwa kurang ada kesadaran dari dalam diri siswa untuk belajar dan berprestasi dengan sebaik mungkin sebagaimana yang sudah menjadi kewajibannya. Siswa belajar dan berusaha melakukan kewajibannya karena adanya tuntutan semata. Di negara lain pun demikian. Menurut Mozaffari (2001), sekitar 
27\% siswa SMA di Iran, memiliki motivasi berprestasi yang rendah.

Dari data-data yang diperoleh, maka perlu dikaji faktor-faktor yang mempengaruhi rendahnya motivasi berprestasi para siswa. Motivasi berprestasi memiliki kaitan erat dengan pendidikan yang diterapkan kepada seseorang. Pendidikan itu sendiri selayaknya tidak hanya diterapkan di sekolah tetapi juga diterapkan di dalam keluarga dan lingkungan. Selain pendidik dan pihak sekolah yang bersangkutan, keluarga dan kepribadian seseorang akan mempengaruhi motivasi berprestasi yang nantinya akan berakibat pada kualitas pendidikan itu sendiri. Murray (Alwisol, 2012) mengatakan bahwa pengasuhan anak mempengaruhi motivasi berprestasi. Pendapat ini juga sama dengan pemikiran bahwa pola asuh berhubungan dengan pretasi anak (Lamban, Mouns, Steinberg, \& Dornbusch, 1991), rasa optimis (Baldwin, Melntyre, \& Hardaway, 2007), rasa percaya diri (Strage \& Brandt, 1999), motivasi (Gonzales \& Wolters, 2006), masalah yang berhubungan dengan perilaku eksternal dan masalah perhatian (Gadeyne, Ghesquire, \& Onghena, 2004).

Pola asuh orang tua adalah konstruk psikologis yang mewakili strategi standar dari orang tua yang digunakan untuk meningkatkan kemampuan anak-anaknya (Kordi \& Baharudin, 2010). Pola asuh mengarah pada perilaku dan strategi yang digunakan orang tua untuk mengendalikan dan mensosialisasikan anak-anak mereka (Lightfoot, Cole \& Cole, 2009 dalam Driscoll, 2013). Pola asuh orang tua berperan aktif dalam perkembangan, kualitas pendidikan serta kepribadian seseorang.

Menurut Baumrind (1971) dalam Driscoll (2013) aspek dari pola asuh orang tua adalah (1) demandingness (permintaan/persyaratan) yang terdiri dari kontrol, pengawasan, permintaan/tuntutan; dan (2) responsiveness (kepekaan) yang terdiri dari kehangatan, penerimaan, dan keterlibatan. Pola asuh orang tua terdiri dari tiga (3) macam yaitu otoriter, otoritatif, dan permisif. Pola asuh otoriter digambarkan sebagai gaya pengasuhan 'hitam dan putih', dimana aturan diharapkan untuk diikuti tanpa ada pertanyaan dan akan ada konsekuensi apabila tidak dilakukan. Orang tua cenderung kaku dan menuntut, sementara tidak ada pertimbangan yang sama yang diperoleh dari anak. Orang tua umumnya tidak responsif terhadap anak-anaknya. Anak-anak yang orang tuanya memiliki pola asuh otoriter, umumnya rendah dalam kesejahteraannya dibandingkan dengan pola asuh lainnya (Steinberg, dkk., 2014 dalam Driscoll, 2013).

Pola asuh otoritatif juga mencirikan adanya aturan yang harus diikuti, namun orang tua cenderung lebih terbuka tentang alasan yang mendasarinya dan masih mempertimbangkan pendapat anak-anak mereka (Baumrind (1971) dalam Driscoll 2013). Pada pola asuh otoritatif, orang tua cenderung membicarakan masalahmasalah dengan anak dalam suasana yang suportif, tidak dalam suasana yang penuh dengan ancaman atau hukuman (Baumrind (1971) dalam Driscoll 2013). Anak-anak yang orang tuanya memiliki pola asuh otoritatif umumnya lebih kompeten dalam hal sosial, emosi, dan kemampuan akademisnya dibandingkan dengan pola asuh lainnya (Steinberg, dkk., 2014 dalam Driscoll, 2013).

Dalam pola asuh permisif, orang tua cenderung lebih responsif dan tidak terlalu menuntut; namun tidak menerapkan kedisiplinan dalam kehidupan sehari-hari (Baumrind (1971) dalam Driscoll 2013). Orang tua umumnya juga komunikatif dan memberikan perawatan yang cukup (Baumrind (1971) dalam Driscoll 2013), sehingga dari pola asuh ini, anak-anak umumnya memiliki kesejahteraan yang tinggi, tetapi rendah dalam prestasi (Steinberg, dkk., 2014 dalam Driscoll, 2013).

Kecenderungan pola asuh permisif mencirikan orang tua yang memiliki kecenderungan memberikan pengontrolan yang kurang terhadap perilaku anak. Pada sikap serba 
boleh, kurang adanya kontrol dari orang tua, anak dapat berbuat sekehendak hatinya, maka anak kurang respek kepada orang tuanya, kurang menghargai apa yang telah diperbuat orang tua untuknya (Hadipranata, Walgito, Adisubroto, Masrun dkk, 2000). Hal tersebut disebabkan karena orang tua yang sangat sayang kepada seorang anak sehingga orang tua memberikan kebebasan anak untuk bertindak. Hubungan orang tua dengan anak menjadi kurang baik karena orang tua kurang memberikan arahan kepada anak dalam bertindak. Hal tersebut mengakibatkan seorang anak kurang mengetahui hak dan kewajibannya, yang seharusnya dilakukan dan yang seharusnya tidak dilakukan sehingga anak kurang memiliki motivasi berprestasi.

Lebih lanjut, orang tua yang lebih perhatian dalam perawatan terhadap anak (dalam pola asuh otoritatif dan permisif) memiliki efek yang positif terhadap harga diri anak-anaknya, sementara orang tua yang terlalu melindungi (overprotective) memiliki efek yang negatif (DeHart, Pelham \& Tennen, 2006 dalam Driscoll, 2013). Kehangatan emosi yang cukup (pada pola asuh otoritatif dan permisif) memiliki hubungan yang positif terhadap kenaikan harga diri, sementara kurangnya kasih sayang, adanya kemarahan, dan penolakan akan memberikan korelasi yang negatif terhadap harga diri (Yang \& Zhou, 2008 dalam Driscoll, 2013). Dengan demikian dapat diperkirakan bahwa pola asuh permisif memberikan kontribusi positif bagi kepercayaan diri.

Pola asuh bukan hanya salah satu faktor yang mempengaruhi motivasi berprestasi. Faktor yang tak kalah penting dalam mempengaruhi motivasi berprestasi yaitu kepercayaan diri. Sebagaimana yang dikemukakan oleh Murray (Alwisol, 2012) bahwa percaya pada diri sendiri mempengaruhi motivasi berprestasi. Adanya pola asuh yang diimbangi dengan kebebasan dan aturan serta memiliki kepercayaan diri maka seseorang juga akan memiliki motivasi berprestasi. Kepercayaan diri adalah kepercayaan seseorang pada kemampuan yang ada dalam dirinya (Hadipranata, Walgito, Adisubroto, Masrun dkk, 2000). Menurut David dan Palladino (Farradina, 2012), rendahnya kepercayaan diri individu menyebabkan rendahnya motivasi. Oleh karena itu, maka orang yang memiliki kepercayaan diri akan bersikap yakin pada kemampuannya sendiri sehingga keberhasilan hidupnya pun diprediksikan akan sesuai dengan hal yang diharapkan.

Fakta di lapangan yang dikemukakan oleh salah satu guru di daerah tertentu mengungkapkan bahwasanya beberapa orang tua menerapkan pola asuh kepada anaknya dengan memberikan kebebasan anak untuk melakukan hal yang dikehendakinya, cenderung memanjakan anak dan kurang memberikan arahan kepada anak. Karena kurang diperkenalkan dengan aturan, maka anak menjadi kurang memiliki kepercayaan diri ketika berada di lingkungan yang penuh aturan seperti sekolah, khususnya ketika menghadapi proses belajar mengajar. Namun ketika berada di lingkungan yang tidak ada aturan maka anak tersebut memiliki kepercayaan diri yang tinggi. Motivasi berprestasi dari anak-anak tersebut juga rendah. Hal tersebut dapat dilihat dari beberapa siswa yang mengobrol dan bermain-main di kelas.

Berdasarkan dari fakta yang diperoleh tersebut, muncul pertanyaan penelitian apakah ada hubungan antara kecenderungan pola asuh permisif dan kepercayaan diri dengan motivasi berprestasi pada siswa?

\section{METODE PENELITIAN}

Prosedur pengambilan sampel pada suatu sekolah di penelitian ini dilakukan dengan cara random atau acak dikenal pula sebagai sampling peluang (probability sampling) yaitu teknik sampling yang memberikan peluang yang sama bagi setiap unsur (anggota) populasi untuk dipilih menjadi anggota sampel (Purwanto, 2012). 
Dalam sekolah yang digunakan pengambilan data, terdapat lima (5) kelas VII, yaitu VII A, VII B, VII C, VII D, dan VII E. Prosedur random yang dipilih dengan menerapkan cluster random sampling dan diperoleh hasil sebagai berikut:

Tabel 1. Jumlah Sampel Penelitian

\begin{tabular}{cccc}
\hline Kelas & Laki-laki & Perempuan & Jumlah Siswa \\
\hline VIIA & 14 & 15 & 29 \\
VIIB & 18 & 14 & 32 \\
\hline \multicolumn{3}{c}{ Total } & 61 \\
\hline
\end{tabular}

Sehingga partisipan yang dilibatkan dalam penelitian ini berjumlah 61 orang. Ke-61 siswa ini diminta untuk mengisi tiga skala, yaitu Skala Motivasi Berprestasi, Skala Persepsi Kecenderungan Pola Asuh Permisif dan Skala Kepercayaan Diri.

Metode yang digunakan untuk analisis data adalah analisis regresi ganda, untuk mencari hubungan antara variabel kecenderungan pola asuh permisif dan kepercayaan diri dengan motivasi berprestasi. Menurut Azwar (2011), dari analisis regresi ganda, kesimpulan yang diperoleh tidak saja berupa penolakan atau penerimaan hipotesis nihil, akan tetapi berupa suatu model persamaan yang berisi kombinasi prediktor terbaik guna memprediksi terhadap variabel Y disertai informasi mengenai besarnya kontribusi masing-masing variabel $\mathrm{X}$ sebagai prediktor.

Penggunaan dari analisis regresi ganda dengan pertimbangan karena terdapat satu variabel tergantung dan dua variabel bebas. Selain itu data dari skala persepsi kecenderungan pola asuh permisif dan kepercayaan diri dengan motivasi berprestasi merupakan data interval. Kemudian dilakukan pengujian hipotesis untuk menunjukkan hubungan dan mengetahui besarnya sumbangan kecenderungan pola asuh permisif dan kepercayaan diri terhadap motivasi berprestasi.

\section{HASIL DAN PEMBAHASAN}

Setelah dilakukan uji homogenitas dan linearitas, selanjutnya dilakukan uji hipotesis. Hasil dari analisis menunjukkan koefisien korelasi sebesar $\mathrm{r}=0,588$ dengan taraf signifikansi $\mathrm{p}=$ $0,000(\mathrm{p}<0,01)$ yang berarti ada hubungan positif yang sangat signifikan antara kecenderungan pola asuh permisif dan kepercayaan diri dengan motivasi berprestasi. Semakin tinggi kecenderungan pola asuh permisif dan kepercayaan diri maka semakin tinggi motivasi berprestasi, dan sebaliknya semakin rendah kecenderungan pola asuh permisif dan kepercayaan diri maka semakin rendah motivasi berprestasi

Berdasarkan hasil korelasi parsial untuk menguji hipotesis selanjutnya yaitu ada hubungan negatif antara kecenderungan pola asuh kecenderungan pola asuh permisif dengan motivasi berprestasi menunjukkan koefisien korelasi sebesar $\left(r_{x 1 y}\right)=-0,295$ dengan taraf signifikansi $\mathrm{p}=0,022(\mathrm{p}<0,05)$ yang berarti terdapat hubungan negatif yang signifikan antara kecenderungan pola asuh permisif dan motivasi berprestasi. Semakin tinggi kecenderungan pola asuh permisif, maka semakin rendah motivasi berprestasi, dan sebaliknya semakin rendah kecenderungan pola asuh permisif, maka semakin tinggi motivasi berprestasi.

Hasil korelasi parsial untuk menguji hipotesis yang terakhir yaitu kepercayaan diri dengan motivasi berprestasi menunjukkan hasil adanya hubungan positif antara kepercayaan diri dengan motivasi berprestasi yang menunjukkan koefisien korelasi sebesar $\left(\mathrm{r}_{\mathrm{x} 2 \mathrm{y}}\right)=0,471$ dengan taraf signifikansi $\mathrm{p}=0,000(\mathrm{p}<0,01)$. Hasil tersebut menunjukkan bahwa ada hubungan positif yang sangat signifikan antara kepercayaan diri dengan motivasi berprestasi. Semakin tinggi kepercayaan diri, maka semakin tinggi motivasi berprestasi, dan sebaliknya semakin rendah kepercayaan diri maka semakin rendah motivasi berprestasi. 
Menurut Hasan \& Khalid (2012) motivasi berprestasi merupakan salah satu dari banyak faktor penting yang menentukan kemampuan akademik siswa. McClelland (Hasan \& Khalid, 2012), mendefinisikan motif berprestasi seperti untuk melakukan sesuatu yang lebih baik, tidak untuk mendapatkan penerimaan atau jenis lain dari imbalan eksternal tetapi untuk kepentingan diri sendiri.

Sebagaimana yang ditulis oleh Kordi dan Baharudin (2010) tentang pemikiran bahwa pola asuh berhubungan dengan prestasi anak (Lamban, Mouns, Steinberg, \& Dornbusch, 1991), rasa optimis (Baldwin, Melntyre, \& Hardaway, 2007), rasa percaya diri (Strage \& Brandt, 1999), motivasi (Gonzales \& Wolters, 2006), masalah yang berhubungan dengan perilaku eksternal dan masalah perhatian (Gadeyne, Ghesquire, \& Onghena, 2004), maka pola asuh akan mempengaruhi motivasi berprestasi siswa. Dalam pola asuh permisif, orang tua cenderung lebih responsif dan tidak terlalu menuntut; namun tidak menerapkan kedisiplinan dalam kehidupan sehari-hari (Baumrind, 1971 dalam Driscoll, 2013).

Pola asuh permisif ditandai dengan membuat beberapa tuntutan, menunjukkan tidak ada kontrol perilaku, dan menggunakan hukuman minimal (Turner, Chandler, \& Heffer, 2009). Turner, Chandler, \& Heffer (2009) menambahkan bahwa dalam pola asuh permisif, orang tua tidak menetapkan aturan dan pedoman untuk perilaku anak mereka.

Joshi \& Acharya (2013) menjelaskan bahwa permisif meliputi pemberian kesempatan kepada anak-anak untuk mengekspresikan pandangannya dengan bebas bertindak sesuai dengan keinginannya tanpa kesimpulan dari orang tua. Dengan kata lain orang tua permisif ditandai dengan penegakan aturan minimum dan memungkinkan anak untuk berperilaku dan bekerja secara independen (Joshi \& Acharya, 2013). Hal tersebut membuat anak bebas untuk bertindak, kurang mengerti akan tanggung jawabnya dan berperilaku kurang sesuai dengan norma dan aturan yang berlaku. Anak-anak yang berada dalam pengasuhan pola ini memiliki kesejahteraan yang tinggi, tapi rendah dalam prestasi. Rendah dalam prestasi karena umumnya anak-anak kurang mendapat pengarahan dari orang tua, kurang adanya tantangan target atau tujuan, dan kurang memiliki tanggung jawab akan tugas dan kewajibannya sehingga motivasi berprestasinya pun rendah. Namun, pola asuh permisif memberikan kontribusi yang tinggi untuk kepercayaan diri. Hal ini diperkuat oleh pendapat dari Driscoll (2013) bahwa pola asuh permisif berhubungan dengan terbentuknya harga diri anak.

Kepercayaan diri memang akan memberikan kontribusi yang besar bagi motivasi berprestasi sehingga umumnya siswa yang memiliki kepercayaan diri yang tinggi pun, prestasinya juga tinggi. Hal ini didukung oleh penelitian dari Panjiang (2009) yang mengatakan bahwa motivasi berprestasi berhubungan dengan penyesuaian dan kepercayaan diri.

Peneliti juga melakukan analisis untuk mengetahui berapa besar sumbangan efektif variabel bebas dalam mempengaruhi variabel tergantung. Hasil analisis pertama menunjukkan bahwa r squared $\left(r^{2}\right)=0,345$ yang menunjukkan bahwa variabel kecenderungan pola asuh permisif dan kepercayaan diri memberikan sumbangan sebesar $0,345 \times 100 \%=34,5 \%$ dalam mempengaruhi variabel motivasi berprestasi. Hasil analisis yang kedua menunjukkan bahwa $\mathrm{r}$ squared $\left(r^{2}\right)=0,062$ dalam hal ini menunjukkan bahwa variabel kecenderungan pola asuh permisif memberikan sumbangan sebesar 0,062 x 100\% $=6,2 \%$ dalam mempengaruhi variabel motivasi berprestasi. Hasil analisis yang ketiga menunjukkan bahwa $r$ squared $\left(r^{2}\right)=0,283$ dalam hal ini menunjukkan bahwa variabel kepercayaan diri memberikan sumbangan sebesar $0,283 \times 100 \%=28,3 \%$ dalam mempengaruhi variabel motivasi berprestasi, selanjutnya sisa sebesar $65,5 \%$ dipengaruhi oleh 
faktor- faktor lain selain kecenderungan pola asuh permisif dan kepercayaan diri. Dengan demikian dapat diterima bahwa terhadap hubungan positif yang sangat signifikan antara kecenderungan pola asuh permisif dan kepercayaan diri dengan motivasi berprestasi. Semakin tinggi kecenderungan pola asuh permisif dan kepercayaan diri, maka motivasi berprestasinya pun juga semakin tinggi. Meskipun pola asuh permisif berhubungan secara negatif dengan motivasi berprestasi, sebagaimana yang diungkapkan oleh Joshi \& Acharya (2013) bahwasanya permisif berkorelasi negatif dengan motivasi berprestasi, namun karena kontribusi kepercayaan diri terhadap motivasi berprestasi cukup besar, yaitu 28,3\% maka kombinasi antara pola asuh permisif dan kepercayaan diri tetap menunjukkan hubungan positif.

Menurut Fernald \& Fernald (Garliah \& Nasution, 2005) beberapa hal yang mempengaruhi motivasi berprestasi selain kecenderungan pola asuh permisif dan kepercayaan diri, adalah kebudayaan, konsep diri (selfconcept), jenis kelamin (sex roles), serta pengakuan dan prestasi (recognition and achievement). Fernald \& Fernald (Garliah \& Nasution, 2005) menambahkan bahwa konsep diri memberikan kontribusi terhadap motivasi berprestasi karena konsep diri memberikan gambaran mengenai dirinya sendiri. Gambaran diri yang positif tentu akan mengarahkan seseorang menuju ke arah positif pula.

Menurut Bernstein (Garliah \& Nasution, 2005), kebudayaan dapat mempengaruhi kekuatan motivasi berprestasi individu. Hal tersebut senada dengan Murray (Alwisol, 2012) yang menyatakan bahwa lingkungan budaya, pekerjaan orang tua dan kelas sosial mempengaruhi motivasi beprestasi. Penjelasan dari beberapa tokoh tersebut dapat memberikan gambaran bahwasanya tidak hanya pola asuh dan kepercayaan diri yang dapat mempengaruhi motivasi berprestasi seseorang. Terdapat faktor lain yang akan mempengaruhi motivasi berprestasi siswa.

\section{KESIMPULAN DAN SARAN}

Kesimpulan dari penelitian ini adalah adanya hubungan positif yang sangat signifikan antara kecenderungan pola asuh permisif dan kepercayaan diri dengan motivasi berprestasi, artinya semakin tinggi kecenderungan pola asuh permisif dan kepercayaan diri maka semakin tinggi motivasi berprestasi, dan sebaliknya semakin rendah kecenderungan pola asuh permisif dan kepercayaan diri maka semakin rendah motivasi berprestasi. Variabel kepercayaan diri memberikan sumbangan yang lebih dominan daripada variabel kecenderungan pola asuh permisif dalam mempengaruhi variabel motivasi berprestasi. Berdasarkan hasil dari penelitian yang telah dilakukan, maka peneliti memberikan beberapa saran bagi peneliti selanjutnya yaitu untuk meneliti secara lebih mendalam mengenai faktorfaktor yang dapat mempengaruhi motivasi berprestasi siswa selain pola asuh dan kepercayaan diri. Peneliti menyarankan kepada pihak-pihak yang terkait yaitu orangtua, sekolah dan siswa yang bersangkutan, jika ingin meningkatkan motivasi berprestasi dapat dilakukan dengan cara menerapkan pola asuh yang sesuai dengan kebutuhan anak dan meningkatkan kepercayaan diri anak.

\section{DAFTAR PUSTAKA}

Aisyah, S. (2010). Pengaruh pola asuh orang tua terhadap tingkat agresivitas anak. Jurnal MEDTEK, 02, 1 - 7.

Akhdinirwanto, R. W. (2011). Peningkatan motivasi belajar fisika melalui metode demonstrasi pada siswa SMP negeri 5 Wates. Prosiding Seminar Nasional Penelitian, Pendidikan dan Penerapan MIPA. Yogyakarta: Mei 14. 
Alwisol.(2012). Psikologi Kepribadian. Malang: UMM Press.

Atmosiswoyo, S., \& Subyakto, H. (2002). Anak Unggul Berotak Prima. Jakarta: Gramedia Pustaka Utama.

Azwar, S. (2005).Tes Prestasi. Yogyakarta: Pustaka Pelajar.

Azwar, S. (2010). Metode Penelitian. Yogyakarta: Pustaka Pelajar.

Azwar, S. (2011). Penyusunan Skala Psikologi. Yogyakarta: Pustaka Pelajar.

Baron, R. A., \& Byrne, D. (2003). Psikologi Sosial. Edisi revisi. Jakarta: Erlangga.

Bee, H \& Boyd, D. 2007. The Developing Child. USA: Paramount Publisher.

Berk, L.E. (1994). Child Development. Boston :Allyn and Bacon.

Chaplin, J.P. (2004). Kamus Psikologi. Jakarta: PT Raja Grafindo Persada.

Dariyo, A. (2004). Psikologi Perkembangan Remaja. Bogor: Ghalia Indonesia.

Davidoff, L. L. (n.d). Psikologi Suatu Pengantar. Jakarta: Erlangga.

Dehyadegary, E., Yaacob, S.N., Bte Juhari, R., Talib, M.A. (2012). Relationship between parenting style and academic achievement among Iranian adolescents in Sirjan. Asian Social Science, 8 (1), 156 - 160.

Driscoll, L.C. (2013). Parenting Styles and Selfesteem. Scripps Senior Theses. Paper 155.

Fatimah, E. (2010). Perkembangan Peserta Didik. Yogyakarta: Pustaka Setia.
Farradinna, S. (2012). Motivasi berprestasi atlet muda dalam menghadapi pekan olahraga nasional tahun 2012 ditinjau dari kepercayaan diri. Psikologika, 17, 53 - 59.

Febriany, R., \& Yusri.(2013). Hubungan perhatian orangtua dengan motivasi belajar siswa dalam mengerjakan tugas-tugas sekolah. Jurnal Ilmiah Konseling, 02, 08 - 16.

Fitriani, A., Arjanggi, R., \& Rohmatun.(n.d). Perception about the system Educate Permisif of Parents with Cinderella Complex at Female Students. Jurnal Proyeksi, 05, 29-38.

Garliah, L., \& Nasution, F. K. S. (2005). Peran pola asuh orang tua dalam motivasi berprestasi. Psikologika, 01, 1 - 10.

Goel, M., \&Aggarwal, P. (2012). A comparative study of self-confidence of single child and child with sibling. International Journal of Research in Social Scienes, 2, 89 - 98.

Gunarsa, S. D., \& Gunarsa, Y. S. D. (2004). Psikologi Praktis: Anak, Remaja dan Keluarga. Jakarta: Gunung Mulia.

Hadipranata, A. F., Walgito, B., Adisubroto, D., Masrun., dkk. (2000). Peran Psikologi di Indonesia. Yogyakarta: Pustaka Pelajar.

Hasan, S. S., \& Khalid, R. (2012). Differences in a achievement motivation and its salient components among high and low achieving students. Pakistan Journal of Psychology, 43, 27 - 40.

Hutapea, B. (2010). Studi komparatif tentang motivasi berprestasi pada atlet kempo propinsi DKI Jakarta ditinjau dari keribadian. Psikobuana, 01, 199-209. 
Hurlock, E. B. (1980). Psikologi Perkembangan. Jakarta: Erlangga.

Indraputra, D. A. (2009). Hubungan intensitas bermain game online dengan Motivasi Berprestasi pada Mahasiswa.Skripsi. (tidak diterbitkan). Yogyakarta: Fakultas Psikologi Universitas Ahmad Dahlan.

Jannah, M. (2013).Hubungan antara konflik peran ganda dan dukun dan suami dengan motivasi berprestasi. Skripsi. (tidak diterbitkan). Yogyakarta: Fakultas Psikologi Universitas Ahmad Dahlan.

Joshi, S., \& Acharya, N. (2013). Home Environment and Achievement Motivation of Adolescene. Sosial Science International, 29, 105 -120.

Junaedit.(2012). 79 Persen Siswa Niat Belajar karena UN. Diunduh dari http:// edukasi.kompas.com/read/2012/04/ $\begin{array}{llllllllllll}2 & 1 & / & 1 & 0 & 5 & 0 & 3 & 8 & 4 & 7 & /\end{array}$ 79.Persen.Siswa.Niat.Belajar.karena.UN. 2 September 2013.

Karwati, E. (2009). Membangun daya saing bangsa melalui pendidikan: refleksi profesionalisme guru di era globalisasi. Seminar Internasional. Bandung.

Kordi, A. \& Baharudin, R. (2010). Parenting attitude and style and its effect on children's school achievements. International Journal of Psychological Studies, 2(2), 217-222

Kusnia, S., \& Rahayu, S.A. (2010). Hubungan antara dukungan sosial dan kepercayaan diri remaja tuna netra. Jurnal Penelitian Psikologi, 01, 40 $-47$.
Lie, A. (2003). 1001 Cara Menumbuhkan Rasa Percaya Diri Anak. Jakarta: PT. Elex Media Komputindo.

Munandar, U. (2003). Kreativitas dan Keterbakatan: Strategi Mewujudkan Potensi Kreatif dan Bakat. Jakarta: PT Gramedia Pustaka Utama.

Nuraeni, D. (2010). Hubungan antara kepercayaan diri dengan kecemasan komunikasi interpersonal pada siswa kelas VII \& VIII di SLTPN I lumbang pasuruan. Skripsi. (tidak terbitkan). Malang: Fakultas Psikologi Universitas Islam Negeri (UIN) Maulana Malik Ibrahim.

Perry, M. (2005).Confidence Booster: Pendongkrak Kepercayaan Diri. Jakarta: Esensi.

Panjiang, P. (2009). Achievement motivation, adjustment and self-confidence among participant and nonparticipants of college activity. $\mathrm{PhD}$ thesis, Universiti Utara Malaysia

Purwanto.(2012). Metode Penelitian Kuantitatif. Yogyakarta: Pustaka Pelajar.

Richards, G. (2010). Psikologi. Yogyakarta: Penerbit BACA.

Rohsantika, N. Y., \& Handayani, A. (n.d). Persepsi terhadap pemberian insentif dengan motivasi berprestasi pada pemain sepak bola. Jurnal Proyeksi, 04, $63-70$.

Rumiani.(2006). Prokrastinasi akademik ditinjau dari motivasi berprestasi dan stres mahasiswa. Jurnal Psikologi Universitas Diponegoro, 03, 37 - 48. 
Santrock, J. S. (2011). Psikologi Pendidikan. Jakarta: Kencana Prenada Media Group.

Sukadji, S., \& Badingah, S. (1994). Pola asuh, perilaku agresif orangtua, dan kegemaran menonton film kekerasan sebagai prediktor perilaku agresif. Jurnal Psikologi. 01: 21-29.

Susanti, F. K. (2008). Hubungan antara kepercayan diri dengan penyesuaian sosial siswa kelas VIII SMP santa maria fatima. Jurnal Psiko-edukasi, 06, 21 - 33.

Thoha, M. (2011).Perilaku Organisasi. Jakarta: Rajagrafindo Persada.

Turner, E. A., Chandler. M., \& Heffer. R. W. (2009). The influence of parenting styles, achievement motivation, and self-efficacy on academic performance in college sudents. Journal of College Student Development, 50, 337 346.
Umasugi, S. C. (2013). Hubungan antara regulasi emosi dan religiusitas dengan kecenderungan perilaku bullying pada remaja. Jurnal Empathy, 02, 01 - 19.

Undang-undang RI nomor 20 tahun, bab 1 pasal 1 (ayat 1) tentang Sistem Pendidikan Nasional. http://UU202003-Sisdiknas.pdf. 2 Maret 2013.

Walgito, B. (2004). Bimbingan dan Konseling (studi dan karir). Yogyakarta: Penerbit Andi.

Wiranegara, C. (2010). Dahsyatnya Percaya Diri: Total Self-Confidence. Yogyakarta: New diglossia.

Yusuf, S. (2007). Psikologi Perkembangan Anak Dan Remaja. Bandung: Remaja Rosdakarya. 